\title{
PEMANFAATAN KULIT SINGKONG MENJADI PAVING BLOCK SEBAGAI UPAYA MENGURANGI TIMBULAN SAMPAH
}

\begin{abstract}
Oleh:
Anis Artiyani*

ABSTRAK: Sampah menjadi masalah lingkungan yang dipandang sebagai buangan yang tidak bermanfaat, yang setiap hari terus meningkat yang tidak sebanding dengan proses pengolahan yang kurang optimal.Sampah yang diolah untuk dipilah menjadi dua bagian yakni organik dan anorganik.Sampah organik diolah untuk dijadikan kompos namun kenyataan masih lemahnya pemanfaatan yang optimal .Sampah Kulit ubi kayu/singkong termasuk dalam kategori sampah organik, karena sampah ini dapat terdegradasi (membusuk/hancur) secara alami.Kulit ubi kayu/singkong sering dianggap remeh dan menjadi limbah rumah tangga padahal ada banyak manfaat yang didapat dari kulit singkong. Meningkatnya pembangunan fisik menyebabkan kebutuhan bahan bangunan juga makin meningkat.Salah satu bahan bangunan yang sering digunakan adalah paving block. Paving block digunakan untuk berbagai macam keperluan seperti tempat parkir mobil di pertokoan, maupun sebagai perkerasan jalan pada komplek-komplek perumahan.Meliahat permasalahan yang ada muncul ide untuk memanfatkan sampah kulit singkong sebagai paving block sebagai upaya mengurangi timbulan sampah.

Metode penelitian yang digunakan adalah penelitian eksperimental yang dilakukan di laboratorium. Variasi penambahan serbuk kulit singkong yang digunakan adalah 0\%, 10\%, 15\%, 30\% dan 60\% untuk mengurangi pemakaian pasir sebagai agregat halus. Dari hasil penelitian membuktikan bahwa (1) sampah kulit singkong memberi pengaruh buruk pada sifat-sifat paving block. (2) Ditinjau dari uji kelayakan paving, paving block sampah kulit singkong yang memenuhi syarat adalah pada penambahan sebesar $0 \%$ s/d $15 \%$ (3) Ketahanan Natrium Sulfat semua paving block yang dibuat dengan penambahan serbuk kulit singkong sampah memenuhi syarat kwalitas paving block untuk tipe I.
\end{abstract}

keyword: kuat tekan, ketahanan natrium sulfat, kulit singkong, paving block

\section{PENDAHULUAN}

Sampah menjadi masalah lingkungan yang dipandang sebagai buangan yang tidak bermanfaat, yang setiap hari terus meningkat yang tidak sebanding dengan proses pengolahan yang kurang optimal. Sampah dibedakan menjadi dua bagian yakni organik dan anorganik. Sampah organik diolah untuk dijadikan kompos bagi tanaman. Sedangkan yang anorganik dibagi lagi menjadi yang bisa didaur ulang dan yang tidak bisa didaur ulang.). Berbagai cara dilakukan untuk menanggulanginya.Mulai dari pembakaran sampah anorganik, pembuatan pupuk kompos dari sampah organik, dan daur ulang sampah, namun, masing-masing cara penanganan sampah tersebut mempunyai kelemahan dan terjadi kekurang optimalan dalam pemanfaatan produk hasil olahan sampah. Kenyataan di sampah hanya dikumpulkan untuk dibuang di tempat pembuangan akhir (TPA), kemudian ditumpuk sehingga bau yang kurang sedap karena terjadi penguraian sampah secara

\footnotetext{
* Dosen Jurusan Teknik Lingkungan Fakultas Teknik Sipil \& Perencanaan Institut Teknologi Nasional Malang.

Alamat koresponden Email: anisartiyani@ymail.com
} 
anaerob. Selain itu, kumpulan lalat di atas sampah dapat menimbulkan berjangkitnya penyakit, yang ang lebih berbahaya lagi akan terjadi rembesan logam-logam berbahaya dalam air tanah atau sumber air dari sampah. Cairan dari sampah yang merembes tersebut disebut leachet. Air leachet ini jika terbawa aliran air, kemudian terserap di dalam tanah akan menimbulkan pencemaran air dan tanah karena air dan tanah telah mengandung bakteri Escherechia coli yang sangat banyak (Rukaesih, 2002). Kenyataan lain sampah yang tidak bisa lagi didaur ulang ini biasanya dibakar di pembakaran akhir sampah karena selain agar tidak menumpuk juga tidak bisa terurai oleh proses biologis (bakteri). Pembakaran sampah menimbulkan masalah baru.Pada pembakaran sampah secara biasa, mengakibatkan pencemaran udara karena sampah yang dibakar menghasilkan gas dioksin yang berbahaya bagi kesehatan.Gas itu bersifat karsinogenik dan dapat menimbulkan kanker. Bahkan, bila terakumulasi di dalam tubuh dapat menimbulkan kematian (http://www.idionline.org. 24 April 2007). SampahKulit ubi kayu/singkong termasuk dalam kategori sampah organik, karena sampah ini dapat terdegradasi (membusuk/hancur) secara alami. Menurut data Badan Pertanian Indonesia (2008), produksi singkong di Indonesia mencapai 20,8 juta ton pertahun, jadi jumlah kulit singkong \pm 364.000 ton pertahun, yang tersebar di Pulau Sumatera, Jawa, Kalimantan, dan Sulawesi. kulit ubi kayu/singkong sering dianggap remeh dan menjadi limbah rumah tangga yang selama ini hanya dibuang ataupun sebagai makanan ternak padahal ada banyak manfaat yang didapat dari kulit singkong, diantaranya digunakan sebagai bahan baku alternatif pembutan paving block.

Meningkatnya pembangunan fisik seperti perumahan, hotel, pusat perbelanjaan, perkantoran dan sarana yang lain menyebabkan kebutuhan bahan bangunan juga makin meningkat, salah satu bahan bangunan yang sering digunakan adalah paving block. Paving block digunakan untuk berbagai macam keperluan seperti tempat parkir mobil di pertokoan, maupun sebagai perkerasan jalan pada komplek-komplek perumahan. Agar pembangunan dapat berlangsung secara berkesinambungan. Pembangunan harus berwawasan lingkungan dengan menggunakan sumber dana secara bijaksana (Otto Sumarwoto, 1992). Tujuan penelitian ini adalah memanfatkan sampah kulit singkong sebagai paving block sebagai upaya mengurangi timbulan sampah. dan mengetahui alternatif komposisi yang terbaik sehingga dapat dihasilkan paving block dengan kualitas yang optimal.

\section{METODE PENELITIAN}

\section{Bahan Pembuat Paving Block Semen Portland}

Semen yang digunakan untuk pembuatan paving block adalah semen portland dari semen $\mathrm{X}$

\section{Agregat}

Agregat yang digunakan terdiri dari pasir sebagai agregat halus dan abu batu sebagai agregat sedang (kasar). Kedua bahan ini dibeli dari toko bahan bangunan di Malang. 
Air

Air yang digunakan adalah air PDAM

\section{Bahan alternatif pengganti pasir}

Bahan alternatif yang digunakan untuk mengurangi pemakaian pasir sebagai agregat halus adalah sampah kulit singkong yang berasal dari home industri keripik singkong didaerah Wagir kota Malang. Sampah kulit singkong yang digunakan merupakan sampah segar kemudian dilakukan penjemuran, dihaluskanyang selanjutnya diayak untuk mendapatkan ukuran partikel yang sama.

\section{Tahapan Penelitian}

Penelitian ini terbagi menjadi dua tahapan kegiatan, yang pertama adalah proses pembuatan proses pembuatan paving block dan yang kedua meliputi uji kelayakan paving block. Adapun tahapan Penelitian dapat di lihat pada Gambar 1.1 berikut ini:

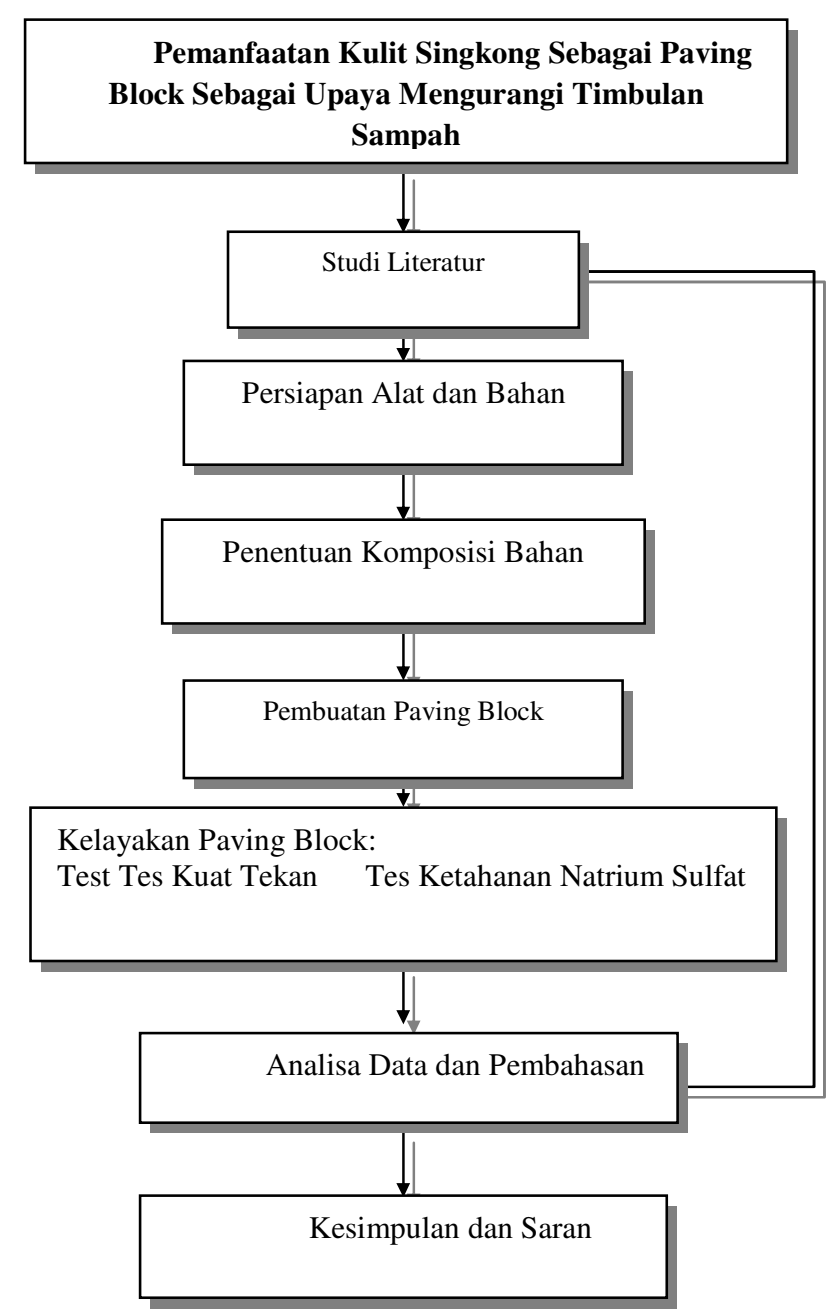

Gambar 1.1 Tahapan Penelitian 
Adapun variasi komposisi bahan dapat dilihat pada Tabel 1.2 berikut:

Tabel 1.2 Variasi komposisi bahan pembuat paving block

\begin{tabular}{|c|c|c|c|c|c|}
\hline \multirow{2}{*}{ No } & \multirow{2}{*}{ Kelompok } & \multicolumn{4}{|c|}{ Perbandingan agregat yang digunakan } \\
\cline { 3 - 6 } & & Semen & $\begin{array}{c}\text { Abu } \\
\text { batu }\end{array}$ & Pasir & $\begin{array}{c}\text { Serbuk kulit } \\
\text { singkong }\end{array}$ \\
\hline 1 & 0 & 1 & 2 & 2 & 0 \\
\hline 2 & 1 & 1 & 2 & 1,5 & 0,5 \\
\hline 3 & 2 & 1 & 2 & 1 & 1,5 \\
\hline 4 & 3 & 1 & 2 & 0,5 & 2 \\
\hline 5 & 4 & 1 & 2 & 0 & 1 \\
\hline
\end{tabular}

Dimana:

1. Kelompok 0 : Kelompok benda uji dengan penambah serbuk kulit singkong sebanyak $0 \%$ dari bagian pasir

2. Kelompok 1 : Kelompok benda uji dengan penambahan serbuk kulit singkong sebanyak $10 \%$ dari bagian pasir.

3. Kelompok 2 : Kelompok benda uji dengan penambahan abu sebanyak $15 \%$ dari bagian pasir.

4. Kelompok 3 : Kelompok benda uji dengan penambahan serbuk kulit singkong sebanyak $30 \%$ dari bagian pasir.

5. Kelompok 4 : Kelompok benda uji dengan penambahan serbuk kulit singkong sebanyak $60 \%$ dari bagian pasir.

\section{HASIL DAN PEMBAHASAN}

\section{Penanganan Kulit Singkong}

Pada penelitian ini kulit singkong yang digunakan berasal berasal dari home industri keripik singkong didaerah Wagir Kota Malang. Sampah ini selanjutnya dijemur dan selanjutnya ditumbuk dan diayak agar nanti didapatkan ukuran patikel yang sama. Dari sampah yang diambil sebanyak $500 \mathrm{~kg}$ sampah dilakukan pemisahan menurut jenisnya.

\section{Uji Kelayakan Paving Block}

Setelah paving block dengan variasi penambahan serbuk kulit singkong telah berumur 28 hari, kemudian dilakukan uji kelayakan kuat tekan dan ketahanan terhadap natrium sulfat. 


\section{Uji Kuat Tekan}

Tabel 1.2 : Hasil pengujian kuat tekan paving block

\begin{tabular}{|c|c|c|c|c|c|}
\hline \multirow{2}{*}{ Kode } & \multicolumn{4}{|c|}{ Perbandingan agregat yang digunakan } & \multirow[t]{2}{*}{$\begin{array}{l}\text { Kuat Tekan Rata-rata } \\
\qquad(\mathrm{kg} / \mathrm{cm} 2)\end{array}$} \\
\hline & Semen & Abu batu & Pasir & $\begin{array}{c}\text { Kulit } \\
\text { Singkong }\end{array}$ & \\
\hline 0 & 1 & 2 & 2 & 0 & 310.00 \\
\hline 1 & 1 & 2 & 1,5 & 0,5 & 198.62 \\
\hline 2 & 1 & 2 & 1 & 1 & 104.50 \\
\hline 3 & 1 & 2 & 0,5 & 1,5 & 89.00 \\
\hline 4 & 1 & 2 & 0 & 2 & 55.25 \\
\hline
\end{tabular}

Dari Tabel 1.2 dapat dilihat bahwa nilai kuat tekan paving block dengan penambahan serbuk kulit singkong mempunyai kecenderungan menurun seiring dengan bertambahnya dosis yang diberikan. Penurunan yang bisa mencapai $80,36 \%$, yakni pada penambahan serbuk kulit singkong sebanyak $60 \%$ dari $310 \mathrm{~kg} / \mathrm{cm}^{2}$ menjadi $55,25 \mathrm{~kg} / \mathrm{cm}^{3}$. Hal ini disebabkan karena sifat serbuk kulit singkong yang lebih lunak dari pasir selain itu, serbuk kulit singkong yang terkandung dalam paving block mengalami proses pembusukan pada saat perawatan paving yang direndam dalam air. Semakin banyak kadar serbuk kulit singkong yang diberikan, maka kuat tekan yang dihasilkan akan semakin menurun pula.

\section{Uji Ketahanan Natrium Sulfat}

Tabel 1.3 : Hasil pengujian ketahanan terhadap Natrium Sulfat paving block

\begin{tabular}{|c|c|c|c|c|c|r|}
\hline \multirow{2}{*}{ No. } & \multirow{2}{*}{ Kode } & \multicolumn{6}{|c|}{ Perbandingan agregat yang digunakan } & Selisih Rata-rata (\%) \\
\cline { 3 - 7 } & & Semen & Abu batu & Pasir & $\begin{array}{c}\text { Kulit } \\
\text { singkong }\end{array}$ & 0.91 \\
\hline 1 & 0 & 1 & 2 & 2 & 0 & 0.83 \\
\hline 2 & 1 & 1 & 2 & 1,5 & 0,5 & 0.77 \\
\hline 3 & 2 & 1 & 2 & 1 & 1 & 0.76 \\
\hline 4 & 3 & 1 & 2 & 0,5 & 1,5 & 0.72 \\
\hline 5 & 4 & 1 & 2 & 0 & 2 & \\
\hline
\end{tabular}

Dari Tabel 1.3 dapat diketahui bahwa semua paving block yang dibuat memenuhi syarat kwalitas paving Block Tipe I yaitu (Normal portland cement), semen portland yang dalam penggunaannya tidak memerlukan persyaratan khusus seperti jenis-jenis lainnya. Digunakan untuk bangunan-bangunan umum yang tidak memerlukan persyaratan khusus 
(SK.SNI T-15-1990-03:2). Hal ini menujukan penambahan serbuk kulit singkong, dapat memperhalus permukaan dari paving block, sehingga larutan perusak Natrium Sulfat akan sulit menembus bagian dalam dari paving block, namun penambahan serbuk kulit singkong dengan selisih berat paving block sebelum dan sesudah perendaman dengan Natrium Sulfat melebihi kadar $1 \%$ tidak dianjurkan, hal ini dikarena sifat Natrium Sulfat yang bersifat merusak ikatan semen akan bekerja semakin hebat pada paving dengan kadar serbuk kulit singkong yang semakin banyak. Larutan ini akan dengan mudah masuk meresap ke dalam paving block dengan campuran serbuk kulit singkong yang memiliki rongga-rongga yang besar serta mudah repuh bila dibandingkan dengan paving block konvensional

\section{KESIMPULAN}

Dari hasil penelitian dapat disimpulkan hal-hal sebagai berikut :

1. Serbuk kulit singkong memberi pengaruh buruk pada sifat-sifat paving block.

2. Nilai maksimum kuat tekan terjadi pada penambahan serbuk kulit singkong optimum sebesar $15 \%$ yang menghasilkan kuat tekan sebesar $104,50 \mathrm{~kg} / \mathrm{cm}^{2}$.

3. Ketahanan Natrium Sulfat semua paving block yang dibuat dengan penambahan serbuk kulit singkong memenuhi syarat kwalitas paving block untuk tipe I. (SK.SNI T15-1990-03:2).

\section{DAFTAR PUSTAKA}

\section{SII.0819-88 "Definisi Paving Block”}

Smith, 1979 dalam Prof Dr Ir Soemarno MS "Pengelolan Kesuburan-Tanah dan Bahan Organik" Jurs Tanah FP UB

(SK.SNI T-15-1990-03:2).

(http://www.idionline.org. 24 April 2007). 